\title{
Perawatan Maloklusi Klas II Divisi 1 Disertai Crowding dan Openbite menggunakan Teknik Begg
}

\author{
Heri Susilo Winarti*, Pinandi Sri Pudyani**, Soekarsono Hardjono**, dan Sri Suparwitri** \\ *Program Studi Ortodonsia PPDGS Fakultas Kedokteran Gigi Universitas Gadjah Mada \\ **Bagian Ortodonsia, Fakultas Kedokteran Gigi Universitas Gadjah Mada \\ *JI Denta no 1 Sekip Utara Yogyakarta, e-mail: weena_dent@yahoo.com
}

\begin{abstract}
ABSTRAK
Maloklusi Angle Klas II divisi I dapat disertai dengan crowding, open bite dan deep bite. Tujuan perawatan adalah untuk mengoreksi crowding, open bite anterior, diastemata rahang bawah, memperoleh overjet dan overbite normal, serta hubungan oklusal yang stabil. Pasien laki-laki berumur 19 tahun, dengan keluhan gigi-gigi rahang atas berjejal dan maju sehingga sulit menutup mulut, serta gigi-gigi rahang bawah renggang. Pasien didiagnosis Maloklusi Angle klas II divisi I dengan hubungan skeletal klas II disetai open bite, crowding dan protrusif gigi-gigi anterior rahang atas, diastemata gigi-gigi rahang bawah, molar pertama bawah kanan dan kiri telah dicabut, dan impaksi gigi kaninus kanan bawah. Perawatan menggunakan teknik Begg yang diawali dengan pencabutan kedua gigi premolar pertama rahang atas. Tahap pertama perawatan menggunakan multiloop arch wire 0,014" dan elastik intermaksiler klas II. Kesimpulan dari hasil perawatan setelah 16 bulan, crowding dan open bite anterior terkoreksi, diastemata menutup, dan pasien sudah tidak kesulitan dalam menutup mulut. Pasien masih dalam tahap penyelesaian perawatan.

Maj Ked Gi. Juni 2013; 20(1): 217-223.
\end{abstract}

Kata Kunci: klas II divisi 1, open bite, crowding, teknik Begg, pencabutan

\begin{abstract}
Treatment Of Clas li Division 1 Malocclusion With Crowding And Open Bite Using Begg Technique. Class II division 1 malocclusion may be accompanied with crowding, open bite and deep bite. The purpose of this treatment is to correct crowding, anterior open bite, general spacing of lower anterior teeth, establish normal overjet and overbite, and obtain stable occlusal relationship. A 19-years-old male patient complained about his crowding and protruding upper teeth and found difficulty to close his mouth. The patient was diagnosed to suffer from class II division 1 malocclusion with skeletal class II relationship accompanied with open bite, crowding and protrusive anterior upper teeth, general spacing of lower anterior teeth. Both sides of lower first molar had been extracted, and the right lower right canine was impacted. Treatment with Begg technique was initiated by extracting two upper first premolars. The first step of treatment was conducted using multiloop arch wire 0,014" and class II intermaxillary elastic. After 16 months of treatment, it is concluded that the crowding and anterior open bite have been corrected, anterior spacing is closed, and the patient no longer find difficulty to close his mouth. The patient is now still under treatment, the final stage. Maj Ked Gi. Juni 2013; 20(1): 217-223.
\end{abstract}

Keywords: class Il division 1, open bite, crowding, Begg technique, extraction

\section{PENDAHULUAN}

Maloklusi Klas II divisi 1 merupakan salah satu maloklusi yang dapat mempengaruhi penampilan seseorang. Karakteristik maloklusi ini adalah profil cembung protrusif, ditandai dengan buccal groove gigi molar pertama permanen bawah terletak lebih ke distal dari tonjol mesiobukal gigi molar pertama permanen atas, dan jarak gigi insisivus tidak normal. Inklinasi gigi insisivus rahang atas labioversi atau protrusif sehingga bibir bawah berada di belakang gigi anterior atas dan bibir atas relatif pendek. Gigi kaninus atas lebih ke depan dari gigi kaninus bawah. Bentuk rahang atas konstriksi pada daerah kaninus, menghasilkan rahang yang lancip atau sempit.

Maloklusi klas Il divisi 1 dapat disertai crowding, deep bite maupun open bite. Open bite merupakan bentuk hubungan yang tidak benar dalam arah vertikal atau tidak berkontaknya gigi-geligi atas dan bawah baik pada regio anterior maupun posterior. ${ }^{2}$ Open bite dibedakan menjadi tipe dental dan skeletal.' Tipe dental terjadi karena kebiasaan buruk atau karena ada objek yang menghalangi erupsi 
gigi (lidah, ibu jari, pensil) tanpa adanya kelainan skeletal. ${ }^{2,3}$ Open bite tipe dental cenderung akan terkoreksi ketika objek yang menghalangi erupsi dihilangkan. Koreksi open bite secara spontan terjadi pada anak-anak usia 7-12 tahun ketika kebiasaan buruk dihentikan. ${ }^{4}$

Maloklusi Klas II divisi 1 dapat disertai hubungan skeletal klas I maupun klas $11 .{ }^{5}$ Maloklusi klas II skeletal menunjukkan adanya diskrepansi anteroposterior antara maksila dan mandibula. Hubungan skeletal klas II dapat disebabkan oleh maksila protrusif dan mandibula normal, maksila normal dan mandibula retrusif, atau maksila protrusif dan mandibula retrusif. ${ }^{6}$

Teknik Begg merupakan teknik yang menggunakan gaya yang ringan dengan archwire berpenampang bulat dan bracket ribbon arch. Archwire akan bergerak bebas tanpa friksi dan menghasilkan gerak tipping bebas mahkota gigi. Salah satu keistimewaan teknik ini adalah kemampuannya menggurangi overjet yang berlebihan melalui pemakaian elastik intermaksiler klas $11 .{ }^{5}$

Tujuan dari artikel ini adalah untuk memaparkan perawatan ortodontik pada Maloklusi Angle klas II divisi I dengan hubungan skeletal klas II disertai open bite, crowding, protrusif gigi-gigi anterior rahang atas dan diastemata gigi-gigi anterior rahang bawah.

\section{LAPORAN KASUS}

Pasien laki-laki usia 19 tahun datang ke klinik ortodonsia RSGM Prof. Soedomo dengan keluhan gigi-gigi rahang atas berjejal dan maju sehingga sulit menutup mulut, serta gigi-gigi rahang bawah renggang. Pemeriksaan intra oral memperlihatkan ukuran lidah sedang, palatum sedang, bentuk lengkung gigi rahang atas dan bawah parabola simetris. Gigi 43 impaksi, gigi 36 dan 46 sudah dicabut. Susunan gigi pada segmen anterior rahang atas crowding berat, gigi-gigi rahang bawah renggang, gigi 13 infraklusi, serta open bite pada gigi 11, 13, 21, 22, 31, 32, dan 41. Hubungan molar pertama kanan dan kiri tidak bisa ditentukan karena molar 1 kanan dan kiri bawah sudah dicabut. Hubungan kaninus kanan tidak bisa ditentukan karena kaninus kanan atas impaksi, sedangkan kaninus kiri klas II. Garis interincisivi rahang atas terhadap rahang bawah tidak segaris, rahang atas bergeser ke kanan sebesar $1,4 \mathrm{~mm}$. Pasien memiliki riwayat kebiasaan buruk berupa bertopang dagu, mengunyah satu sisi, kerot dan mendorong lidah, yang pada waktu dilakukan pemeriksaan masih sering dilakukan.

Hasil analisis sefalometri menunjukkan hubungan skeletal klas II dengan dengan maksila protrusif dan mandibula retrusif disertai bidental protrusif. Analisis jaringan lunak menunjukkan bibir atas dan bibir bawah terletak lebih ke depan dari garis Steiner (protrusif).

Perawatan yang akan dilakukan bertujuan untuk mengoreksi crowding, open bite anterior, diastemata rahang bawah, memperoleh overjet dan overbite normal, serta hubungan oklusal yang stabil. Kebutuhan ruang untuk kasus ini adalah sebesar $11 \mathrm{~mm}$ untuk segmen rahang atas, $6,7 \mathrm{~mm}$ kanan dan 4,3 mm kiri. Kekurangan ruang yang dibutuhkan diperoleh dengan pencabutan kedua premolar pertama. Kebutuhan ruang pada rahang bawah didapat dengan memanfaatkan ruang bekas pencabutan gigi 36 dan 46. Kelebihan ruang pada rahang bawah akan ditutup dengan mesialisasi gigi posterior.

Jenis penjangkaran yang digunakan adalah penjangkaran maksimum pada rahang atas yaitu gigi-gigi penjangkar tidak boleh bergerak ke mesial dan penjangkaran minimum untuk rahang bawah yaitu gigi-gigi penjangkar masih memungkinkan untuk bergerak ke mesial.

Tahap perawatan disusun berdasarkan tahaptahap pada metode Begg. Tujuan tahap pertama perawatan teknik Begg antara lain: mengatur letak gigi (unravelling) dengan koreksi bukolingual dan rotasi, memperbaiki ketidakteraturan dalam arah vertikal (levelling), koreksi hubungan incisivus menjadi edge to edge (tepi lawan tepi), koreksi overbite dan memperbaiki hubungan oklusi posterior. Tujuan tahap ke dua adalah penutupan sisa ruang bekas pencabutan gigi (space closing) dengan menarik gigi posterior ke mesial. Tahap ketiga dilakukan untuk memperbaiki inklinasi aksial gigi anterior. 
Perawatan menggunakan teknik Begg diawali dengan pencabutan kedua gigi premolar pertama rahang atas dan gigi kaninus kanan bawah yang impaksi karena posisinya tidak memungkinkan untuk dilakukan retraksi ke posisi yang seharusnya. Tahap awal dilakukan levelling dan unraveling untuk mengoreksi crowding berat pada gigi-gigi anterior rahang atas, general diastema pada rahang bawah, openbite di regio anterior dan gigi 13 infraklusi. Levelling menggunakan australian wire 0,014" yang dilengkapi dengan vertical loop antara gigi 13-12, 12 11, 11-21, 21-22, 22-23, 31-32, 32-33, 31-41, 41-42, 42-43 dan anchorage bend $15^{\circ}$. Elastik intermaksiler klas II 5/16" 2 oz yang dikaitkan dari circle hook gigi 13 ke buccal tube gigi 47 dan dari circle hook gigi 23 ke buccal tube gigi 37. Levelling dan unravelling pada rahang atas dan bawah dicapai setelah 3 bulan perawatan, selanjutnya dilakukan retraksi gigi-gigi anterior rahang atas menggunakan elastik intermaksiler klas II 5/16" 2oz, australian archwire 0,016 " dan anchorage bend $15^{\circ}$. Retraksi gigi anterior rahang atas tercapai dalam waktu 3 bulan. Gigi 44 dilakukan mesialisasi untuk menggantikan gigi 43 yang impaksi. Mesialisasi dilakukan menggunakan elastik 1/8" 4 oz yang dikaitkan pada pin gigi 42 ke pin gigi 44, gigi anterior diligasi. Setelah gigi 44 berkontak dengan gigi 42 , gigi 44 diligasi ke gigi anterior.

Perawatan masih dalam tahap II yaitu mesialisasi gigi posterior kanan rahang bawah. Rencana perawatan selanjutnya melanjutkan mesialisasi gigi posterior kanan rahang bawah, penyesuaian oklusi dan pemakaian retainer. Hasil perawatan ortodontik yang telah dilakukan selama 16 bulan, telah menunjukkan perubahan seperti terlihat pada foto muka (Gambar 1 dan 2), foto intra oral (Gambar 3 dan 4), foto OPG (Gambar 5A dan 5B), foto sefalometri (Gambar 6A dan 6B) serta hasil analisis sefalometri sebelum dan sesudah perawatan ortodontik selama 16 bulan menggunakan alat cekat teknik Begg. Analisa sefalometri sebelum dan sesudah perawatan dapat dilihat dalam Tabel 1 .

Tabel 1.Pengukuran sefalometri sebelum dan sesudah perawatan selama 16 bulan

\begin{tabular}{lcccc}
\hline \multicolumn{1}{c}{ Pengukuran } & Nilai Normal & $\begin{array}{c}\text { Sebelum } \\
\text { Perawatan }\end{array}$ & $\begin{array}{c}\text { Sesudah } 16 \text { bulan } \\
\text { perawatan }\end{array}$ & Perubahan \\
\hline Facial angle & $82^{\circ}-92^{\circ}$ & $76^{\circ}$ & $74^{\circ}$ & $2^{\circ}$ \\
Angle of convexity & $-8,5^{\circ}-+10^{\circ}$ & $16^{\circ}$ & $21^{\circ}$ & $5^{\circ}$ \\
Bidang A - B & $-9-0^{\circ}$ & $-5^{\circ}$ & $-12^{\circ}$ & $6^{0}$ \\
FMPA & $17^{\circ}-28^{\circ}$ & $41^{\circ}$ & $42^{\circ}$ & $1^{\circ}$ \\
Y axis & $53^{\circ}-66^{\circ}$ & $75^{\circ}$ & $77^{\circ}$ & $2^{\circ}$ \\
SNA & $82^{\circ}$ & $83^{\circ}$ & $83^{\circ}$ & $0^{\circ}$ \\
SNB & $80^{\circ}$ & $76^{\circ}$ & $76^{\circ}$ & $0^{\circ}$ \\
ANB & $2^{\circ}$ & $7^{\circ}$ & $7^{\circ}$ & $0^{\circ}$ \\
Go.Gn-SN & $32^{\circ}$ & $42^{\circ}$ & $43^{\circ}$ & $1^{\circ}$ \\
$\mathrm{U}_{1}-\mathrm{L}_{1}$ & $130^{\circ}$ & $94^{\circ}$ & $120^{\circ}$ & $26^{\circ}$ \\
$\mathrm{U}_{1}-\mathrm{NA}$ (sudut) & $22^{\circ}$ & $35^{\circ}$ & $11^{\circ}$ & $24^{\circ}$ \\
$\mathrm{U}_{1}-\mathrm{NA}$ (mm) & $4 \mathrm{~mm}$ & $10,5 \mathrm{~mm}$ & $1 \mathrm{~mm}$ & $9,5 \mathrm{~mm}$ \\
$\mathrm{~L}_{1}-\mathrm{NB}$ (sudut) & $25^{\circ}$ & $46^{\circ}$ & $39^{\circ}$ & $7^{\circ}$ \\
$\mathrm{L}_{1}-\mathrm{NB}$ (mm) & $4 \mathrm{~mm}$ & $13 \mathrm{~mm}$ & $12 \mathrm{~mm}$ & $1 \mathrm{~mm}$ \\
IMPA & $81,5^{\circ}-97^{\circ}$ & $107^{\circ}$ & $101^{\circ}$ & $6^{\circ}$ \\
Occl pl - SN & $14^{\circ}$ & $10^{\circ}$ & $15^{\circ}$ & $5^{\circ}$ \\
Occl pl - FHP & $1,5^{\circ}-14,3^{\circ}$ & $9^{\circ}$ & $14^{\circ}$ & $5^{\circ}$ \\
Overbite & $2-4 \mathrm{~mm}$ & $0,1 \mathrm{~mm}$ & $1,36 \mathrm{~mm}$ & $1,26 \mathrm{~mm}$ \\
Overjet & $2-4 \mathrm{~mm}$ & $4,1 \mathrm{~mm}$ & $2,48 \mathrm{~mm}$ & $1,62 \mathrm{~mm}$ \\
\hline & & & & \\
\hline
\end{tabular}


Heri S. W., dkk.: Perawatan Maloklusi Klal II Divisi I ...

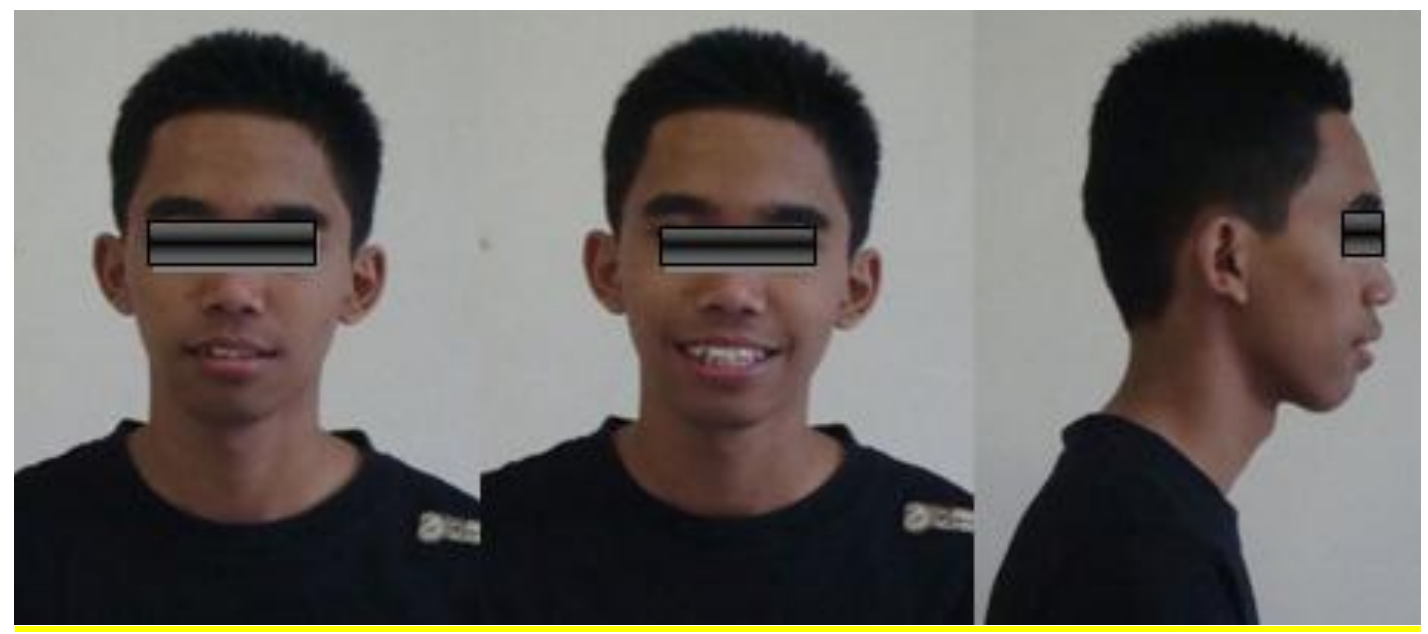

Gambar 1. Foto muka sebelum perawatan ortodontik.

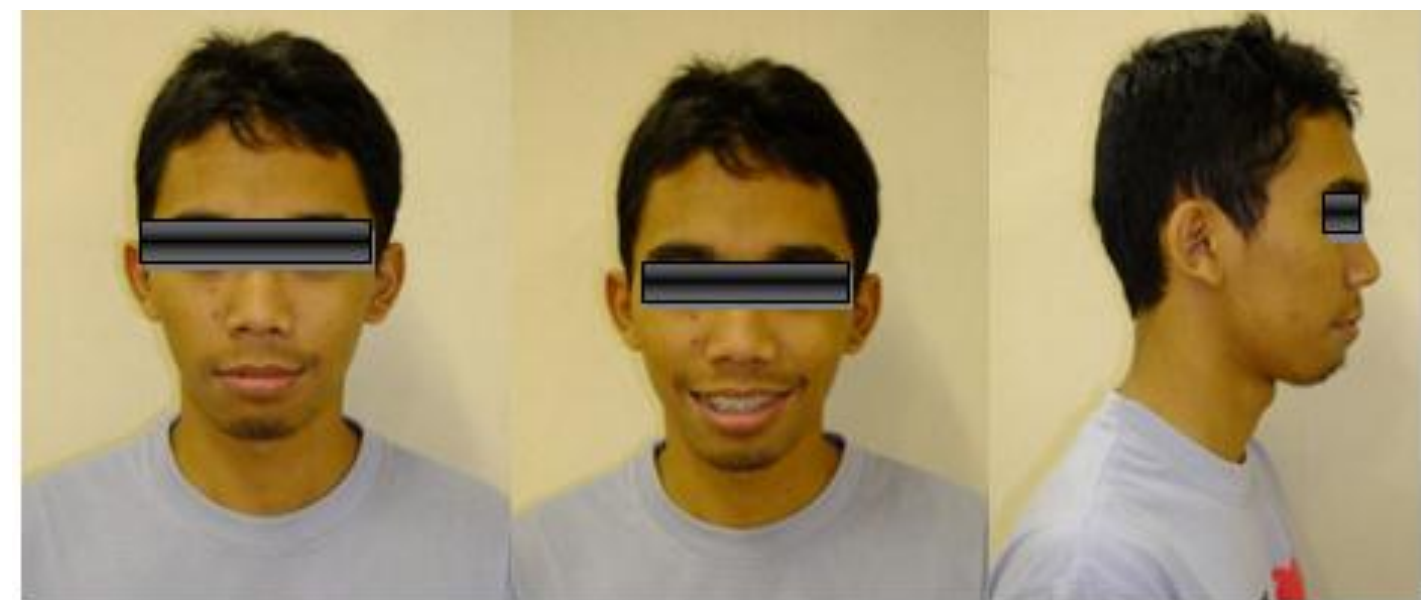

Gambar 2. Foto muka setelah 16 bulan perawatan ortodontik
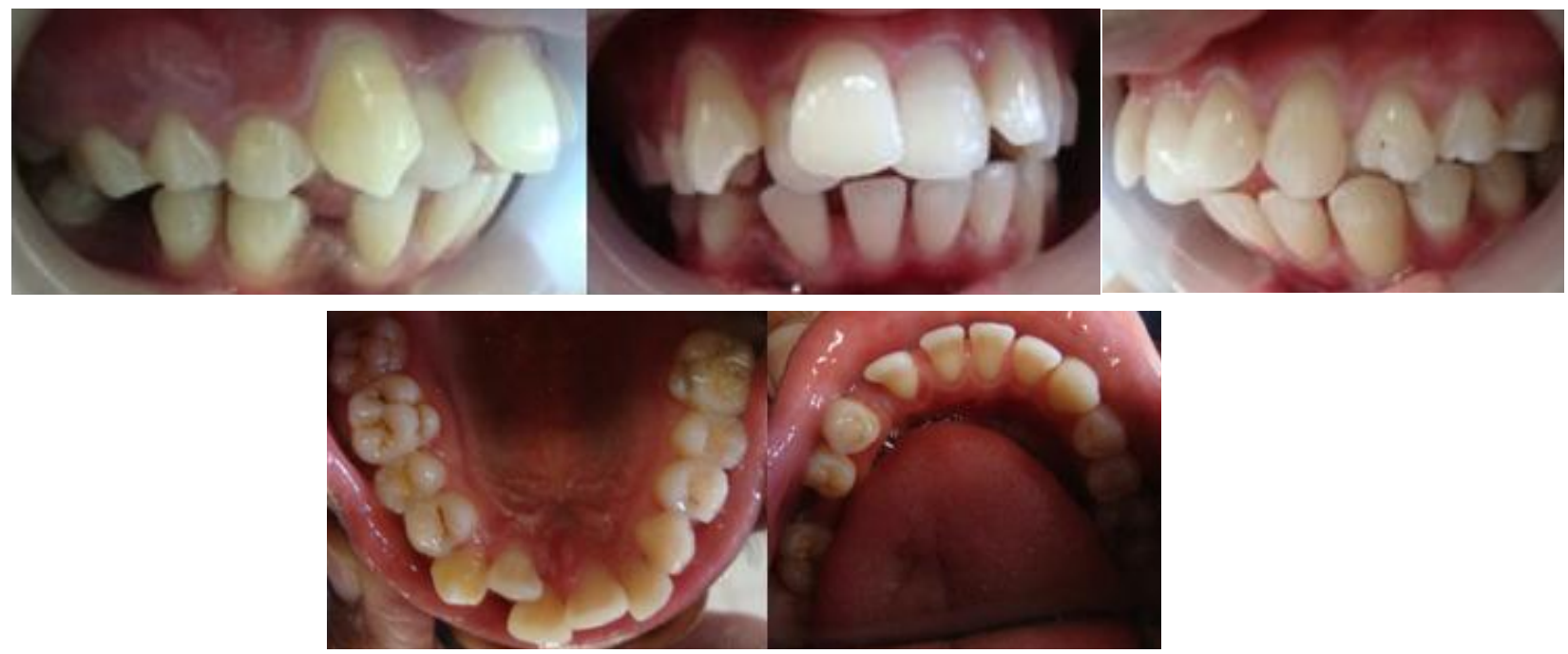

Gambar 3. Foto intra oral sebelum perawatan ortodontik. 

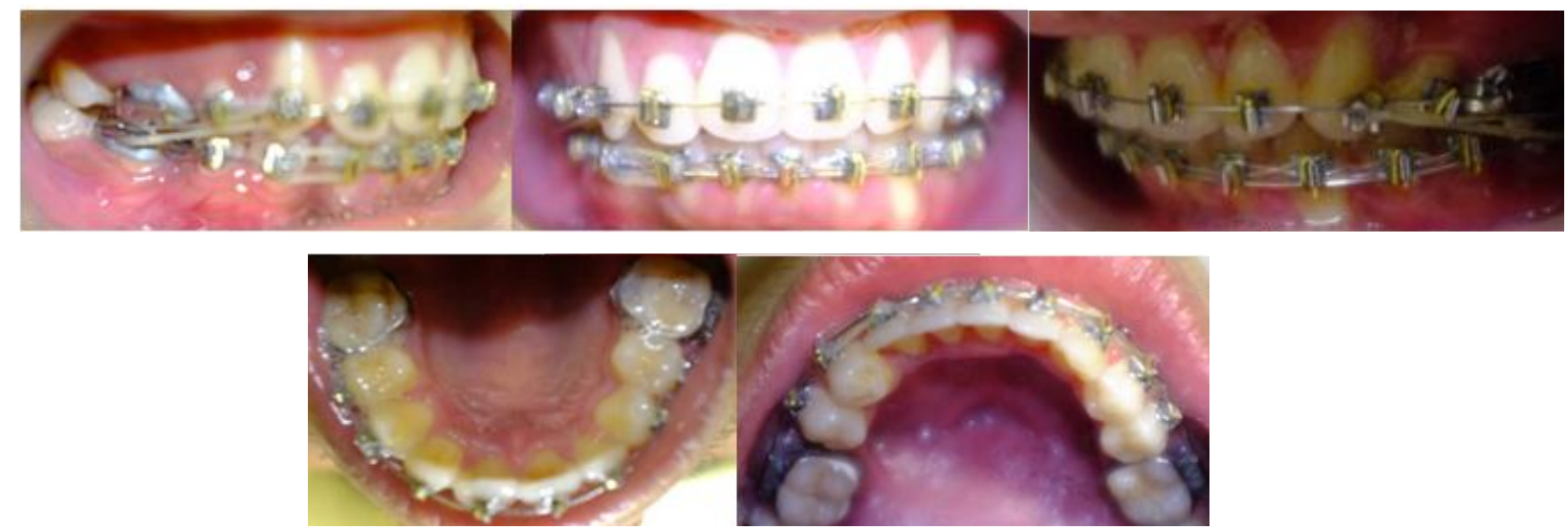

Gambar 4. Foto intra oral setelah 16 bulan perawatan ortodontik.

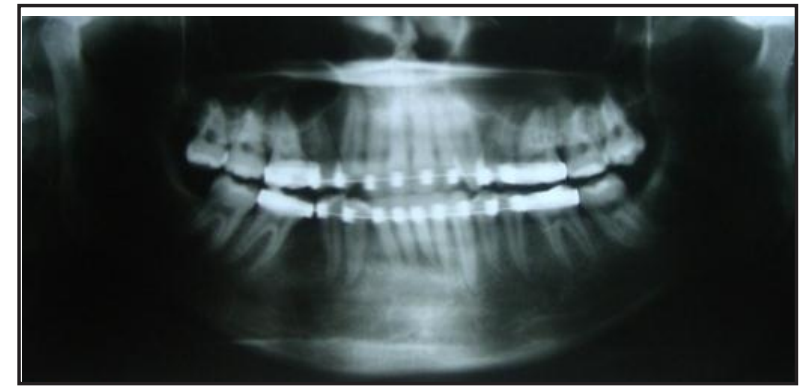

(A)

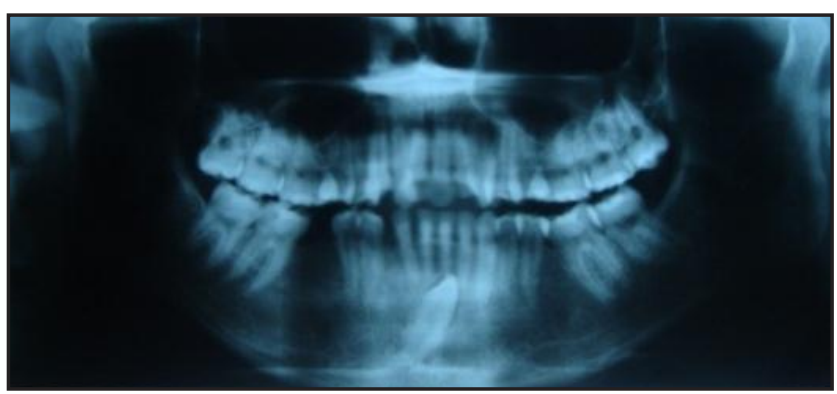

(B)

Gambar 5. (A) Foto OPG sebelum perawatan ortodontik (B) Foto setelah 16 bulan perawatan ortodontik.

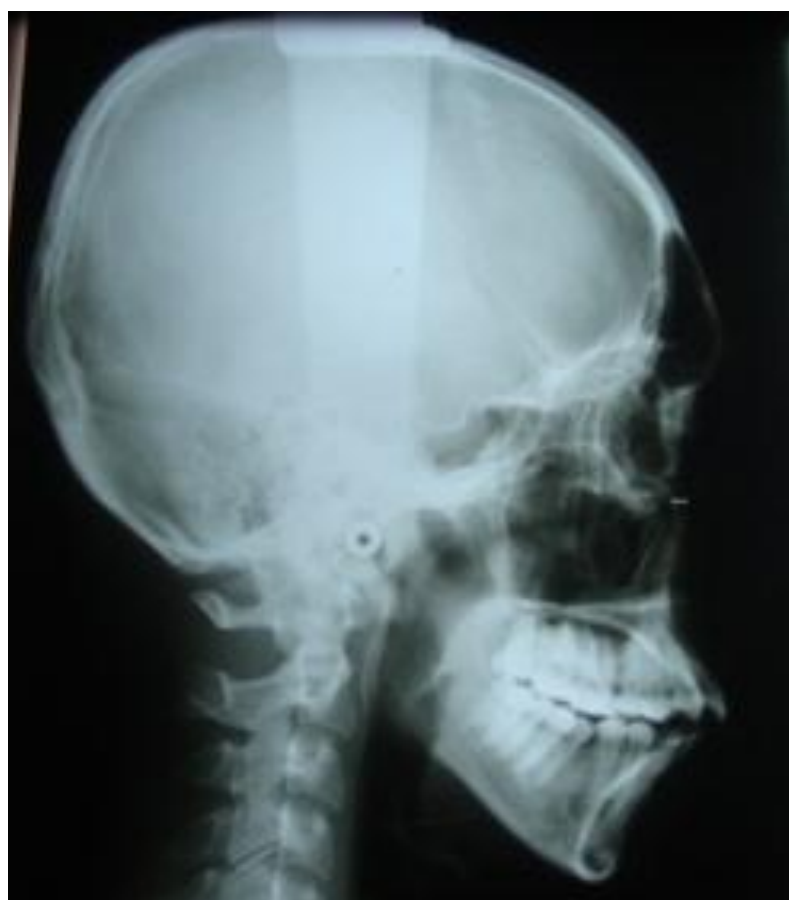

(A)

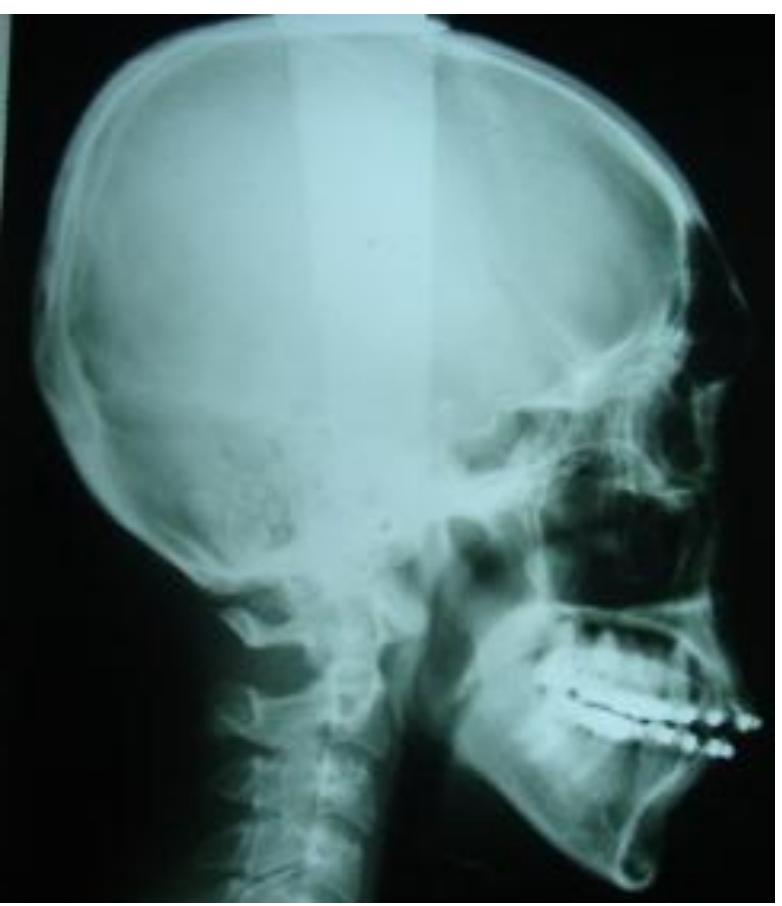

(B)

Gambar 6. (A) Foto sefalometri sebelum perawatan ortodontik (B) Foto setelah 16 bulan perawatan ortodontik. 


\section{PEMBAHASAN}

Berdasarkan pemeriksaan klinis, analisis model studi dan analisis sefalometri, menunjukkan bahwa kasus ini merupakan maloklusi klas II divisi 1 (berdasarkan hubungan kaninus kiri) dengan hubungan skeletal klas II, maksila protrusif dan mandibula retrusif. Terdapat crowding berat pada gigi-gigi rahang atas dan general diastema pada gigi-gigi rahang bawah serta open bite di regio anterior akibat adanya kebiasaan buruk pasien yaitu sering mendorong lidah yang sekarang sudah tidak dilakukan lagi.

Hasil perawatan setelah 16 bulan terlihat crowding dan open bite anterior terkoreksi, diastemata menutup, dan pasien sudah tidak kesulitan dalam menutup mulut. Perubahan bermakna juga ditemukan pada profil muka pasien karena adanya perubahan inklinasi gigi incisivus rahang atas. Hasil analisis sefalometri setelah 16 bulan menunjukkan adanya perubahan yang bermakna pada pengukuran: facial angle, angle of convecity, bidang A-B, FMPA, Y aksis dan GoGnSN. Perubahan ini disebabkan karena pemakaian elastik intermaksiler klas II sehingga terjadi rotasi mandibula searah dengan jarum jam. Sudut SNA, SNB maupun ANB tetap, tidak adanya perubahan ini disebabkan karena perawatan masih dalam tahap II. Titik A dapat berubah karena pertumbuhan dan gaya mekanis. ${ }^{8}$ Retraksi gigi anterior dapat mempengaruhi letak titik A yang terletak di daerah apeks incisivus atas. Retraksi gigi incisivus pada teknik begg menghasilkan gerakan tipping mahkota gigi incisivus ke posterior dan apeks gigi incisivus ke arah anterior. Gerakan tipping tersebut dikoreksi dengan pemakaian auxillary torquing pada tahap III yang akan menggerakkan akar gigi ke arah palatal. ${ }^{9}$ Perubahan titik B tergantung dari kedudukan mandibula akibat adanya rotasi mandibula. Hasil pengukuran: $U_{1}-L_{1}, U_{1}-N A, L_{1}-N B$ menunjukkan perubahan bermakna. Perubahan ini disebabkan karena adanya perubahan inklinasi gigi incisivus atas akibat retraksi gigi anterior rahang atas. ${ }^{7}$

Overjet berkurang dari 4,1 $\mathrm{mm}$ menjadi 2,48 $\mathrm{mm}$ dan overbite bertambah dari $0,1 \mathrm{~mm}$ menjadi $1,36 \mathrm{~mm}$. Hal ini disebabkan karena retraksi gigi anterior rahang atas. Mekanisme perawatan menggunakan teknik Begg juga memungkinkan terjadinya pengurangan overjet melalui pemakaian elastik intermaksiler klas $11 .^{5}$ Overbite sudah mendekati normal, namun belum normal. Hal ini mungkin disebabkan karena masih adanya traumatik di gigi pada gigi 15 dan gigi 45, sehingga dengan mesialisasi gigi 45 diharapkan overbite menjadi normal.

Perawatan pasien belum selesai karena baru sampai pada perawatan tahap II. Gigi 44 dilakukan mesialisasi untuk menggantikan gigi 43 yang impaksi. Mesialisasi dilakukan menggunakan elastik 1/8" $4 \mathrm{oz}$ yang dikaitkan pada pin gigi 42 ke pin gigi 44, gigi anterior diligasi. Setelah gigi 44 berkontak dengan gigi 42, gigi 44 diligasi ke gigi anterior. Dilanjutkan mesialisasi gigi 45 dan 47 dengan cara yang sama. Gigi 12 masih sedikit ekstrusi. Hal ini disebabkan karena posisi awal gigi 12 yg ekstrusi dan terletak di palatal gigi 11 dan terjepit diantara gigi 13 dan 11 , sehingga tidak memungkinkan untuk penempatan bracket pada posisi yg benar. Selanjutnya dilakukan reposisi bracket 12 untuk memberi efek intrusi pada 12.

Setelah semua terkoreksi dilanjutkan koreksi inklinasi aksial pada tahap III, menggunakan auxillary antara lain uprighting spring untuk menegakkan gigi yang tipping, dan palatal root torque untuk menggerakkan akar gigi incisivus rahang atas ke arah palatal. ${ }^{5}$

\section{KESIMPULAN}

Perawatan Maloklusi klas II divisi 1 dengan hubungan skeletal klas I, crowding dan open bite anterior terkoreksi, diastemata menutup, dan pasien sudah tidak kesulitan dalam menutup mulut dalam masa perawatan 16 bulan. Pasien masih dalam tahap penyelesaian perawatan.

\section{DAFTAR PUSTAKA}

1. Cangialosi TJ. Skeletal morphologic features of anterior open bite. Am J Orthod. 1984; 85(1): 28-35.

2. Muslim, Siregar E. Perawatan ortodontik gigitan terbuka anterior dengan pola pertumbuhan wajah hyperdivergen. JKGUI. 2003;10: 169-77. 
3. English J. Early treatment of skeletal open bite malocclusion. Am J Orthod and Dentofac Orthop. 2002; 121: 563-5.

4. Worms F, Meskin LH, Isaacson RJ. Open bite. Am J Orthodont. 1971: 59: 589-95.

5. Begg PR, Kesling PC. Begg orthodontic theory and technique. Ed 2. Philadelphia: W.B. Saunders Co; 1977. H. 140-65.
6. Profit WR. Contemporary orthodontics. St. Louis: The CV Mosby Co; 2007. H. 153-4.

7. Holdaway RA. Change in relationship of point a and point $b$ during orthodontic treatment. Am J Orthod. 1956; 42: 176-93.

8. O'Reilly MT. Treatment and post treatment changes with the begg appliances. Am J Orthod Dentofac Orthop. 1979; 75(5): 535-47. 